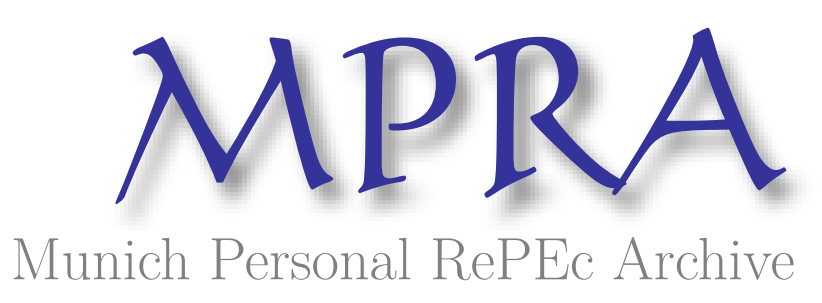

\title{
Inventory and the Stock Market
}

Lai, Richard

Harvard Business School

6 January 2006

Online at https://mpra.ub.uni-muenchen.de/4760/

MPRA Paper No. 4760, posted 07 Sep 2007 UTC 


\title{
Inventory and the Stock Market
}

\author{
Richard Lai*
}

January 6, 2006

How does the stock market affect inventory decisions? The "efficient markets" view is that low stock price means poor fundamentals, a higher cost of capital, and lower inventory. Normatively, firms should obtain their cost of capital from an efficient markets model of stock prices. My study is motivated by the growing body of evidence that the stock market is not efficient and can temporarily mis-value firms. I report evidence that the market's "behavioral" component explains firms' inventory as much as its "fundamentals" component. I further test three possibilities for how the behavioral component works. The first is a financing channel. When the market over-values firms, firms can get cheaper financing and increase inventory. The second is dissipation. When the market mis-values firms, firms are less disciplined and let inventories rise. The third is catering. When the market discounts high-inventory firms, firms decrease inventory, and vice versa. I report evidence that weakly supports financing, rejects dissipation and strongly supports catering. The findings suggest that we need to find new ways of calculating the cost of capital for operations models. They could begin to form the basis of a more empirically accurate account of how inventory decisions are affected by financial markets.

JEL classification: D24, D82, M11

* Harvard Business School, rlai@hbs.edu, tel: 617495 6228. Honorable mention at INFORMS/MSOM Student Paper Competition, 2005. I thank participants at conferences and many in the HBS Finance Unit and the Harvard Economics Department for ideas, feedback, and instruction. I especially thank Josh Lerner for detailed feedback and Ananth Raman and Vishal Gaur for continuous inspiration and support. All errors are mine. 


\section{Inventory and the Stock Market}

\section{Introduction}

How does the stock market affect inventory decisions? One view, associated with Tobin (1969), is the "efficient markets" view. It assumes that stock prices accurately reflect investment "fundamentals" - the opportunities and risks, and therefore the marginal cost of capital. This view has positive and normative implications. The positive one is its description of how stock price correlates with inventory: low stock price means poor fundamentals, a higher cost of capital, and lower inventory. The normative implication is that a firm can obtain its cost of capital from an efficient markets model of stock prices (see Stein (1996)). This is the cost of capital that the efficient markets view prescribes, to be plugged into foundational formulations in operations management such as the EOQ (economic order quantity) and news-vendor solutions.

My study is motivated by the growing body of evidence that the stock market is not efficient. In the inefficient markets view, the stock market can temporarily over- or under-value firms, even if this mis-valuation works itself out of stock prices over time. In the last decade, a vast number of empirical studies interpret their findings as evidence that markets are inefficient. Finance theory has also begun to show that it takes very lax assumptions for inefficiency to obtain. For example, inefficient markets can hold even if transactions are costless. Baker, et al. (2004), Barberis and Thaler (2003), and Shleifer (2000) summarize the theory and evidence. In the operations management literature, some studies now also report abnormal stock prices (e.g., Chen, et al. (2005)). 
If true, this inefficient markets view could dramatically revise the positive and normative implications described in the first paragraph. Normatively, "it is no longer obvious that one should set hurdle rates using [the efficient market models]" (Stein (1996), pg. 431), such as CAPM (capital asset pricing model) or linear multifactor models like Fama and French (1993). The positive story of how stock prices correlate with inventory also needs to be revised, since firms' inventory decisions might be different with mis-valuation.

In this paper, I empirically test the inefficient markets view. First, I test whether the stock market's "behavioral" component (if it exists) affects inventory. Second, I test how this happens.

To investigate the first, I test a null "fundamentals only" hypothesis, that the stock market has no impact on firms' inventory levels other than through fundamentals. To investigate the second, I consider three possible channels through which inefficient markets might affect inventory. One possibility is a financing channel. For financially constrained firms, overvaluation allows them to raise financing and increase inventory to optimal levels (e.g., Stein (1996) and Baker, et al. (2003) describe similar stories for capital expenditure and dividend policies). Another possibility is a dissipation channel, based on the idea of shirking in principalagent models (e.g., Baker (1992)). When the market mis-values firms, firms become less disciplined and let inventories rise. The third is a catering channel. When the market discounts high-inventory firms, firms decrease their inventory. When the market places a premium on inventory, firms increase their inventory (e.g., see Baker and Wurgler (2004) for catering to a dividend premium).

To test the "fundamentals only" hypothesis, my baseline model regresses inventory on behavioral and fundamental components of the stock market. The data is from the merged 
COMPUSTAT-CRSP tapes, ExecuComp, I/B/E/S, CDA, The Wall Street Journal, and a variety of other sources detailed later. I take care to address the econometric challenges in the estimation. For example, to measure unobservable variables like the behavioral component, I use a variety of measures, as in Baker and Wurgler (2004) and Polk and Sapienza (2004). Some example measures of the behavioral component are CAPM and Fama-French alphas, earnings accruals, and the closed-end fund discount. I also instrument some of these variables and use fixed effects. Another econometric challenge is potential endogeneity, which I handle with a range of lag structures. In the baseline model and all its variants, I find that the behavioral component is an important explanation for inventory, after controlling for fundamentals. A typical univariate regression of inventory on the behavioral component (measured using CAPM alpha) has an $R$ squared of about $24.4 \%$. The coefficient on the component, even after partialling out fundamentals, is statistically and economically significant. One standard deviation change in the behavioral component correlates with a $10 \%$ standard deviation change in inventory. This compares well with the economic significance of the fundamentals (measured using cash flow growth), where a standard deviation change correlates with a $28 \%$ standard deviation change in inventory.

I report some evidence consistent with the financing channel but not with the dissipation channel, and strong evidence of catering. In regressions of inventory on fundamentals and the three channels, the latter account for an adjusted $R$-squared of $64.7 \%$, but the bulk of this $(63.7 \%)$ is by the catering channel.

These results contribute to a deeper understanding of the interaction between operations management and finance. For example, they could begin to form the basis of a more 
empirically accurate model of how inventory decisions are made (e.g., Netessine and Roumiantsev (2005)). This in turn might go some distance in addressing the concern "often made [about inventory models, that] any resemblances between the models constructed and reality are purely coincidental" (Whitin (1952)).

The findings can also open up new avenues of research. For example, a natural question is whether the welfare implication of catering is positive for managers, shareholders, firms, and society. With regard to the last, the resulting misallocation of resources over time is more severe than misallocation in a cross-section of firms. As pointed out by Morck, et al. (1990), misallocation in a cross-section could at least be mitigated by the fact that overall inventory levels are approximately unaffected. Too little inventory in one department store might be compensated by more at another. However, misallocation over time is irrevocably more damaging to the economy at large.

Finally, the findings can have important practical implications. At the macroeconomic level, Blinder and Maccini (1991) document that inventory changes account for $87 \%$ of the total peakto-trough movement in GNP. Clearly, an understanding of how and why inventory changes is important for management of the economy. At the level of the firm, if catering is mostly a loss for shareholders, for example, it could be an important and not-yet-well-understood consideration for managerial compensation and other aspects of firm management.

\section{Inventory and the Stock Market}

The question of whether and how the stock market affects inventory has a parallel in the macroeconomics and corporate finance literature. However, there, the dependent variable is corporate investments rather than inventory. The literature divides into two camps. On one 
side, Tobin (1969) initiates a literature that relates investments to $q$, a summary statistic for the stock market's information about the firm's fundamental investment costs and opportunities. Market sentiment does not play a role. On the other side, theorists as early as Keynes (1936) argue that stock prices have a behavioral component so that they diverge from fundamental information about investments.

The modern incarnation of Keynes' idea is an inefficient market. It has three components. First, there are noise traders who hold beliefs ("sentiment") that cannot be rationally justified. Second, these traders' activities do not cancel out. Third, there are limits to arbitraging away the uncancelled activities. (Following the literature, I use the terms "inefficient market," “irrational market," “behavioral market," “sentiment," and "mis-valuation" interchangeably.)

Early empirical work does not have a consensus. For example, Barro (1990) argues that the stock market "dramatically out-performs" fundamental variables such as $q$ and cash flow, in explaining investment levels. On the other hand, Blanchard, et al. (1990) state that "market valuation appears to play a limited role, given fundamentals, in the determination of investment decisions." Morck, et al. (1990) conclude with a hedge, that "the market may not be a complete sideshow, but nor is it very central."

Fortunately, recent work, such as those by Baker, et al. (2003) and Polk and Sapienza (2004), produce more persuasive evidence in favor of the inefficient markets view. The reason recent empirical studies show progress is that they return to the theory of why inefficient markets might affect investments. Specifically, they test the channels through which the stock market might influence investments. This is the approach I take in this paper.

The first possible channel is financing. The idea is that some firms are financially 
constrained, so they are not able to carry the optimal amount of inventory. If the market is inefficient, temporary over-valuation of these firms allows them to raise funding at a lower cost of capital (see Brainard and Tobin (1968), Fischer and Merton (1984) for similar arguments for investments). This lower cost of capital could come directly from the lower cost of equity issuance, or indirectly by the lower cost of debt with expanded debt capacity or reduced overhang. This view is empirically distinguishable from the other channels I discuss latter. Specifically, the financing hypothesis predicts that, in a cross-section, only constrained firms increase inventory; while unconstrained firms may also take advantage of over-valuation to obtain financing, this financing is unlikely to increase inventory, which is ex ante optimal.

Another possible channel is dissipation. The idea is that during periods of mis-valuation (either over- or under-valuation), firms let inventories rise unnecessarily, dissipating value that is otherwise captured with more efficient operations. The story is consistent with principalagent models such as Baker (1992). In these models, effort by the agent (managers) to keep inventory optimally low is costly and inherently unobservable to the principal (shareholders). Thus, the agent's effort is only weakly linked to reward. With inefficient markets, the effortreward link is further weakened. First, reward often depends on valuation, whether explicitly or implicitly. Valuation now has an exogenous behavioral component, adding more noise to the effort-reward link. Second, the principal reduces monitoring of inventory levels when misvaluation encourages other priorities, such as equity issuance when there is over-valuation (hence the interaction with the financing channel) or investor communications when there is under-valuation. Still, the dissipation channel is empirically distinguishable from the other channel in two ways. First, in cross-sections, the dissipation channel applies to weakly 
governed firms. Second, the financing channel predicts that inventories will be overly high during over-valuation and overly low during under-valuation, while dissipation is predicted to occur in both times of over-valuation and under-valuation.

The dissipation channel might seem to be related to the free cash-flow hypothesis of Jensen (1986), in which firms left with too much cash dissipate them with empire-building. However, the motivating factor there is excess cash rather than mis-valuation. It is also important to clarify that the dissipation channel does not suggest that there is no dissipation without misvaluation. Instead, it predicts that dissipation increases with mis-valuation, and particularly so in weakly governed firms.

The third channel is catering. Managers cater to the interest of the stock market, even if this catering is at the expense of long-term shareholder value. Managers cater because of short-term interests, as pointed out by Stein (1988). For example, their compensation might be a function of short-term stock price. They might also need to sell off their shares in the firm periodically, so they ensure that the firm is not undervalued. Or they might keep the firm's short-term value high to avoid being its being taken-over by buyout firms that might fire them. Or they might want to ensure that their reputation and worth in the executive market is high, as in the careerconcerns models of Narayanan (1985) and Holmstrom (1999).

While the financing and dissipation channels depend on stock market mis-valuation in general, the catering channel depends on a specific kind of mis-valuation based on inventory. When there is an "inventory discount," managers cater to the market by reducing their inventories. Conversely, when there is an inventory premium, managers increase inventories. The inventory discount/premium is analogous to similar phenomena studied in other areas of 
market inefficiency, such as the small firm premium (Roll (1983)), close-end mutual fund premium (Boudreaux (1973), Lee, et al. (1991)), or the dividend discount/premium (e.g., Baker and Wurgler (2004)). This dependence on an inventory discount (if it exists) empirically distinguishes the catering channel from the other two. Another point of distinction is that the catering channel plays a bigger role in firms that are more short-term, such as those whose executives' compensation disproportionately emphasizes stocks and options. A particularly strong cross-sectional test is whether we see catering in the current period stronger among firms whose executives exercise their options in the next period.

Where does the inventory discount come from? It might arise because it is difficult to read what high inventory really means (e.g., Lai (2005)). It could mean operational incompetence and sagging sales, or it could mean a high-responsiveness strategy and good prospective sales. Further, at any one time, the beliefs of investors, especially noisy traders, tend to herd (e.g., Scharfstein and Stein (1990)). Therefore, we might see an inventory discount one time and a premium at another. Aghion and Stein (2005) provide a formal model of how this can happen.

A concluding clarification: it might seem that the inefficient market arguments above require that firms or managers to be smarter than the market to detect mis-valuation, and to ignore market signals. It is a standard result in the literature that only a less restrictive interpretation is needed (e.g., Stein (1996)). Specifically, the firm could use a Bayesian combination of its private information and the market's valuation. In the catering case, firms "may just cater to, or even be forced by proxy vote to meet, extreme investor demands in general, and mis-pricing is merely a symptom of extreme investor demand. In this interpretation, managers are not knowingly outwitting the market. Their decisions will still 
generate return predictability, but they are not explicitly designed to capture mis-pricing." (Baker and Wurgler (2004), pg. 1155).

\section{Testing the "Fundamentals Only" Hypothesis}

The empirical strategy is to first test the "fundamentals only" hypothesis: whether the stock market's behavioral component (if any) affects inventory. If the "fundamentals only" hypothesis is rejected (which I will show), the second part of the empirics is to test the channels with which the behavioral component affects inventory.

The key challenges are the identification of the unobservable behavioral component, as well addressing potential endogeneity, since inventory and the right-hand-side variables can be simultaneously determined or there might be reverse causality. I address these in this section.

\subsection{Data}

The data is from COMPUSTAT-CRSP, ExecuComp, I/B/E/S, CDA, The Wall Street Journal, and a variety of other sources detailed below. I update all COMPUSTAT-CRSP data with restated values - e.g., for sales, assets, cost of goods sold. To be included in the dataset, I follow the practice in the literature (e.g., Morck, et al. (1990), Polk and Sapienza (2004), Gompers, et al. (2003), Baker, et al. (2003)): observations cannot be involved in acquisitions or mergers, the market-to-book and $q$ must be between 0.1 and 100, sales, assets, capital expenditures, income before earnings and interest, common dividends, common equity must all have non-negative values, and outliers are dealt with by winsorizing at the $1 \%$ and $99 \%$ percentiles. The summary statistics are in Table 1.

\subsection{Model}

The theory that the stock market affects inventory only through fundamentals maps into an 
empirical specification in a straightforward way. The null is that $\beta_{2}$ below vanishes:

$$
\begin{gathered}
\text { INVENTORY } Y_{i t}=\beta_{0}+\beta_{1 .} \text { FUNDAMENTALS } S_{i t}+\beta_{2} . \text { BEHAVIORALi,t-1 }+ \\
\text { firm effects }+ \text { year effects }+\varepsilon_{i t},
\end{gathered}
$$

where $i$ and $t$ index firms and years, and $\varepsilon$ is white. I use this specification in two baseline models. In the first, I use differences with OLS (ordinary least squares) rather than levels with fixed effects, to make the results comparable with Morck, et al. (1990), a major paper in the field. In the second, I use levels with fixed effects, comparable with the more recent literature such as Polk and Sapienza (2004).

Except for BEHAVIORAL, equation (1) is essentially the standard q-theoretic investment equation (e.g., Summers (1981)). BEHAVIORAL is lagged while FUNDAMENTALS is contemporaneous because I am interested in whether the former affects INVENTORY beyond its ability to predict the latter. It is possible, however, that lagging BEHAVIORAL might provide FUNDAMENTALS with an informational advantage. But including contemporaneous measures of BEHAVIORAL (unreported) do not change the results, a finding consistent with Poterba (1990).

When using differences, I measure INVENTORY using growth in inventory value, analogous to the growth in capital expenditure in Morck, et al. (1990). When using fixed effects, I measure INVENTORY by scaling inventory value with property, plant, and equipment, as in Polk and Sapienza (2004). For further robustness, I also use the adjusted inventory in Gaur, et al. (2005). ${ }^{1}$

I also measure FUNDAMENTALS using different variables. In the differences model, these are net sales growth and cash flow growth, following Morck, et al. (1990). They measure 
expected opportunities and the cost of capital, respectively. A very different measure of FUNDAMENTALS is to use the $q$ variable, following Polk and Sapienza (2004). This has the additional advantage that $q$ could capture parts of BEHAVIORAL (see Abel and Blanchard (1986)), so that the estimated coefficient of BEHAVIORAL is likely to understate its importance. However, the standard measure of observable $q$ itself introduces the well-known problem that it is a poor proxy for marginal $q$. Fortunately, this is generally resolved in the literature as not an important measurement problem empirically (see, for example, Abel and Blanchard (1986)).

I measure BEHAVIORAL using several variables. One is abnormal stock returns. Following Morck, et al. (1990), I employ alphas under a CAPM (capital asset pricing model) model, using annual market and risk-free returns from Professor French's website. ${ }^{2}$ CAPM alpha has the advantage that it could understate the effect of BEHAVIORAL on INVENTORY, because if part of the CAPM alpha is really compensation for risks, that part is a fundamental parameter (being expected, not abnormal, return) that should, if anything, depresses INVENTORY.

The second measure uses the more recent model by Fama and French (1993) for abnormal returns, based on SML ("small minus large"), HML ("high book-to-market minus low"), and UMD ("up momentum versus down") factors, also obtained from Professor French.

The third directly measures "sentiment." I use the close-end fund discount, which has the well-known characteristic that stock price often differs from net asset value in such funds, because unsophisticated investors hold different beliefs than others. This difference is generally regarded as a measure of the market's behavioral component (e.g., Zweig (1973), Long, et al. (1990), Lee, et al. (1991)). The literature is still ambivalent about the source of this component (e.g., whether it reflects changing risk tolerance or growth expectations, see Baker and Wurgler 
(2004)), but my goal is to measure it rather than to achieve the more ambitious objective of studying it per se. Following Baker and Wurgler (2004), I obtain the value-weighted closed-end fund discount from Neal and Wheatley (1998) (for years 1962 through 1993), CDA (1994 through 1998), and The Wall Street Journal end-of-year issues (1999 through 2000).

The fourth measure of BEHAVIORAL follows Polk and Sapienza (2004). I use discretionary accruals. Sloan (1996) and Teoh, et al. (1998) find that such accruals lead to lower stock returns, which can be interpreted as over-valuation. This argument relies on investors not being sophisticated enough to see through the manipulation of accruals, a fact well-documented in the accounting literature (e.g., Maines and Hand (1996)). There are many models for measuring discretionary accruals, but as Dechow, et al. (1995) show, the main models are about equally accurate, although the Jones (1991) model has the best statistical power. Therefore, I measure discretionary accruals as total accruals less normal accruals, following Jones (1991) and Teoh, et al. (1998). Total accruals are defined as:

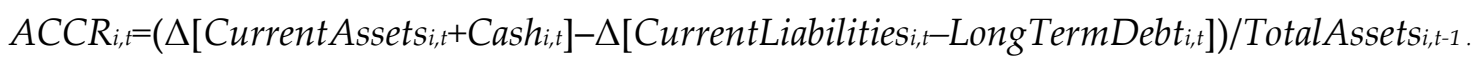

For each firm, I then derive its non-discretionary accruals by first running a cross-section regression using the firm's four-digit SIC code peers (i.e., all but itself):

$$
\begin{gathered}
\text { ACCR } \left.\left._{i, t}=\theta_{0}+\theta_{1} .(1 / \text { TotalAssets } i, t-1)\right)+\theta_{2 .}\left(\Delta \text { sales }_{i, t} / \text { TotalAssets } i, t-1\right)\right)+ \\
\theta_{3 .}\left(\text { PlantPropertyEqpt }_{i, t} / \text { TotalAssets }_{i, t-1}\right)+\varepsilon_{i, t .}
\end{gathered}
$$

Using the predicted coefficients $\hat{\theta}$ from above, the firm's non-discretionary accruals are:

$$
\begin{aligned}
& \text { NONDIS-ACCR } R_{i, t}=\hat{\theta}_{0}+\hat{\theta}_{1 .}\left(1 / \text { TotalAssets }_{i, t-1}\right)+ \\
& \left.\hat{\theta}_{2 .}\left(\Delta \text { sales }_{i, t}-\Delta \text { accountsReceivable } i, t\right)\right) \text { TotalAssets }, t-1_{+}+ \\
& \left.\hat{\theta}_{\text {3.(PlantPropertyEqpt }}, t \text { TotalAssets }{ }_{i, t-1}\right) \text {. }
\end{aligned}
$$


Discretionary accruals are then defined as the difference between total and nondiscretionary accruals. One advantage of using discretionary accruals is that it could understate the effect of BEHAVIORAL. As Chan, et al. (2001) document, firms with high discretionary accruals tend have low cash flows (a fundamental parameter), so that even if accruals might be correlated with FUNDAMENTALS, they are so only negatively.

The different measures of BEHAVIORAL have two important properties. First, they enhance robustness because they work through different mechanisms in mis-valuation. For example, the closed-end fund discount operates through differences in clientele segments while discretionary accruals work through information distortion. Second, they are all linked to cross-sectional patterns in returns that are not well-explained by standard asset pricing models.

\subsection{Results}

Table 2 shows the baseline results, in models (1) through (4). These replicate the first two models in Morck, et al. (1990) and those in Polk and Sapienza (2004). Like them, I find that $B E H A V I O R A L$ is an important driver of inventory decisions, with both a substantial $R$-squared (24.4\%, comparable to the $20.8 \%$ in Morck, et al. (1990)) and positive significant sign. Model (2) partials out FUNDAMENTALS, and the resulting coefficient on BEHAVIORAL drops substantially, but is still very statistically significant. Models (3) and (4) obtain the same, despite using different estimation methods (fixed effects) and different measures of INVENTORY, BEHAVIORAL, and FUNDAMENTALS. In each, the R-squared is significant, and $B E H A V I O R A L$ is once again significant and signed as predicted.

The economic significance of BEHAVIORAL varies. For the closed-end fund discount measure of BEHAVIORAL, a one standard deviation change in BEHAVIORAL leads to a $10 \%$ 
standard deviation change in INVENTORY, while the CAPM alpha measure produces only a $3 \%$ standard deviation change in INVENTORY. The important point is that these are still comparable with those of FUNDAMENTALS. For example, a standard deviation change in cash flow growth correlates with a $28 \%$ standard deviation change in INVENTORY, while for lagged $q$, it is just $6 \%$.

\subsection{Robustness Checks}

There are some other empirical issues to address:

1. Horizon to take in difference specification. Morck, et al. (1990) use three-year horizons to "capture delayed changes in investment." I expect that inventories, unlike their capital expenditures, are adjustable much faster over time. Also, a longer horizon has the disadvantage that the specification is more susceptible to endogeneity. For example, in $q$ theory, the desired level of capital stock might not follow a deterministic trend over longer periods. In any case, I regress over both one- and three-year horizons and the results are qualitatively unchanged.

2. Additional controls. Like Morck, et al. (1990), I use industry dummies and find that the results (unreported) are qualitatively unchanged. Furthermore, I use year dummies (reported here), whose inclusion means a more stringent test because they understate the effect of $B E H A V I O R A L$ if they pick up time variations of the aggregate stock market. I also cluster regressions around firms, to minimize serial correlation.

3. Discretized dependant variables. One problem with INVENTORY is that it could be measured with error. Following Morck, et al. (1990), one way to address this is to discretize it, using a dummy which is set to 1 if the change in inventory exceeds a 
threshold and 0 otherwise. Importantly, this also weakens the contending interpretation that small inventory changes are not the result of conscious firm policy, but involuntary changes. Model (5) shows the result of a logistic regression using a discrete version of INVENTORY, in which the dummy is 1 if $\Delta$ inventory is more than 1.2 and 0 otherwise. The results are qualitative unchanged from the earlier models, as are those (unreported) using different thresholds for creating the dummy variable.

4. Lag structures. Lags help minimize simultaneity issues. I use zero to four lags in the specifications. In this paper, I report results from estimations using no lags for OLS regressions and two lags for fixed effect regressions; other specifications give qualitatively similar results, unless otherwise stated.

5. Reversed causality and simultaneity. Reversed causality is handled by lagging BEHAVIORAL. It is still possible that the measures of FUNDAMENTALS such as sales and cash flow are simultaneously determined with the stock returns used to measure $B E H A V I O R A L$. Suppose a good past return increases inventories because of lower costs of financing, but increased inventories improve sales because of better availability. Therefore, measuring FUNDAMENTALS with sales would pick up some effect of the influence of returns on inventories. First, this only understates the effect of BEHAVIORAL, thus strengthening the finding. Second, in Model (6), I use all the previous measures of BEHAVIORAL as instrument variables for the Fama-French alpha measure, in a two-stage least squares estimation. The $p$-value of an over-identifying restriction test is 0.03 , suggesting that the 2 SLS is valid. In any case, the instrumented result is qualitatively unchanged. Third, simultaneity seems unlikely from model (2), 
which shows that doubling sales would increase inventory by $49.3 \%$. The mean sales-toinventory ratio is 27.7 and the median is even lower, at 6.6. Therefore, most of the sales increase does not come from inventory increase.

6. Truncation and possible sample selection bias. One of the usual problems with using COMPUSTAT-CRSP data is truncation bias, because some firms are not documented in the earlier years. To deal with this, I use a Heckman sample selection correction. The first-stage correction model for firm-year observations is:

$$
\text { SELECTED }=f(M K T C A P, S \mathcal{E P 5 0 0 ,} \text { ASSETS }),
$$

where MKTCAP is market capitalization, $S \mathcal{E P} 500$ is whether the firm is ever in the S\&P 500, and ASSETS is total assets. Model (7) shows that the result is qualitatively the same. The inverse Mill's ratio is marginally significant at $7.9 \%$. A possible reason that the bias is small is that the long period of coverage overwhelms the shorter period of truncation. To simplify the exposition in the rest of the paper, I present results without the Heckman correction, after checking that the corrected results are qualitatively unchanged. There is also possible survivorship bias: the dataset might contain surviving firms that are different from those dropped. For this, I create a sub-sample that truncates five years out of the beginning and end of my dataset. Again, the result is qualitatively unchanged so I do not report this to save space.

\section{Testing the Channels}

The data for these tests are the same as that for the previous section, except for a few sources that I describe below. 


\subsection{The Financing Channel}

I add variables measuring the volume of past equity and debt issuance:

$$
\begin{aligned}
\text { INVENTORY }_{i t} & =\beta_{0}+\beta_{1} . \text { FUNDAMENTALS }_{i t}+\beta_{2} . \text { BEHAVIORALit-1 }+ \\
& \gamma_{1 .} \text { EQUITY }_{i, t-1}+\gamma_{2} . \text { DEBT }_{i, t-1}+\text { firm effects }+ \text { year effects }+\varepsilon_{i t} .
\end{aligned}
$$

I should see that the $\gamma$ coefficients are positively signed and $\beta_{2}$ drops in economic significance. I measure EQUITY using two methods. One, following Morck, et al. (1990), divides common equity by beginning-of-year market capitalization, and a more sophisticated way, by Daniel and Titman (2003), considers equity issuance, employee stock and pension plans, repurchases, and dividends. Specifically, the latter, which I will call DT equity, can be interpreted as the (log of the) number of shares one would have at time $t$ for every share one owns at $t-\tau$, had one reinvested all cash distributions back into the stock. It is defined as:

$$
\text { DT equity }=\log \left(M_{t} / M_{t-\tau}\right)-r(t-\tau, t) \text {. }
$$

$M_{t}$ is the per share value at $t$ and $r(t-\tau, t)$ is the log stock return from $t$ - $\tau$ to $t$, in turn defined as:

$$
r(t-\tau, t)=\sum_{s=t-\tau+1}^{t} \log \left[\left(M_{s .} f_{s}+D_{s}\right) / M_{s-1}\right]
$$

where $f_{s}$ is the price adjustment factor from $s-1$ to $s$ that accounts for splits and rights issues, and $D_{s}$ is the per-share cash distribution paid at time $s$.

I measure DEBT using book debt. EQUITY and DEBT are interpreted as specialized measures of BEHAVIORAL that account for the financial channel which with BEHAVIORAL might influence INVENTORY. For example, Daniel and Titman (2003) document how their measure of equity issuance predicts subsequent low stock returns, suggesting current over- 
valuation.

Empirically, data on these are often inaccurate, so Morck, et al. (1990) suggest using indicator variables, where EQUITY is 1 if the change in equity is over $5 \%$ and DEBT is 1 if the change in debt is over $10 \%$. This provides a less stringent test. As will be seen, the financing channel is not well supported, so using this method allows me to see if the hypothesis is indeed weak even when given benefit of the doubt.

The financing channel makes another prediction that I can use as a still more robust test: financially-constrained (or small, as a proxy) firms should be even more susceptible to the effect of the stock market. To test this, I augment the specification in (2) to:

$$
\begin{aligned}
& \text { INVENTORY } Y_{i t}=\beta_{0}+\ldots \text { as before } \ldots+\gamma_{1} . E_{\text {QUITY }} Y_{i, t-1}+\gamma_{2} . D E B T_{i, t-1}+ \\
& \text { 1.EQUITY }{ }_{i, t-1} \times \text { FINANCIALLY-CONSTRAINED } D_{i t}+ \\
& \delta_{2 .} \text { DEBT }_{i, t-1} \times \text { FINANCIALLY-CONSTRAINED } D_{i t}+ \\
& \text { firm effects }+ \text { year effects }+\varepsilon i \text {. }
\end{aligned}
$$

Positively-signed $\delta$ coefficients would be consistent with the financing channel.

A measure of FINANCIALLY-CONSTRAINED would include standard corporate finance parameters such as firm size, firm age, leverage, cash balance, cash flow, cash volatility, and investment opportunities. Kaplan and Zingales (1997) incorporate these in an index. The advantage of this $\mathrm{KZ}$ index is that it is transparent and, having been built from scratch for a different purpose, is unlikely to be biased for my purpose.

\subsection{The Dissipation Channel}

The dissipation channel predicts a quadratic relationship in BEHAVIORAL:

$$
\text { INVENTOR }_{i t}=\beta_{0}+\beta_{1} . \text { FUNDAMENTALS } i t+\beta_{2} . B E H A V I O R A L_{i, t-1}+
$$




$$
\text { 33.BEHAVIORAL }{ }^{2} i, t-1+\text { firm effects }+ \text { year effects }+\varepsilon_{i t} .
$$

Unlike the financing channel, the dissipation channel is motivated by an agency problem between manager and shareholder. Therefore, it also predicts that in a cross section, firms with bigger agency problems have more dissipation. I test for this by modifying specification (1) as follows, where $G$ is a governance index from I/B/E/S calculated by Gompers, et al. (2003):

$$
\begin{aligned}
& \text { INVENTORY }_{i t}=\beta_{0}+\beta_{1} . \text { FUNDAMENTALS }_{i t}+\beta_{2} . \text { BEHAVIORAL }{ }_{i, t-1}+\beta_{3} . \text { BEHAVIORAL }^{2}, t-1+ \\
& \zeta_{1} G_{i t}+\zeta_{2 .} \text { BEHAVIORALi,t-1 } \times G_{i t}+\zeta_{3 . B E H A V I O R A L 2}{ }_{i, t-1} \times G_{i t}+ \\
& \text { firm effects }+ \text { year effects }+\varepsilon_{i t} \text {. }
\end{aligned}
$$

A positively signed $\zeta_{2}$ and negatively signed $\zeta_{3}$ are consistent with the dissipation channel.

\subsection{The Catering Channel}

The biggest empirical challenge to testing the catering channel is in measuring the inventory discount. I use measure the discount in many different ways to minimize measurement problems. Structurally, each measure divides the dataset into low- and high-inventory firmyear observations and the inventory discount is the difference by some measure (say the mean market-to-book ratio) between these two sub-samples. For the choice of dividing into low- and high-inventory observations, I use a variety of criteria: (1) inventory value levels, (2) inventory value changes, (3) inventory value divided by property-plant-equipment value, (4) inventory/PPE changes, (5) inventory/sales based on the adjusted-inventory-turn specification in Gaur, et al. (2005), and (6) inventory/sales changes. For the choice of measuring the difference between the low- and high-sub-samples, I use the log of the difference in the marketto-book (MTB) ratios and the future one-year, two-year, three-year, and cumulative three-year stock returns (please see Baker and Wurgler (2004) for a similar set-up for calculating the 
dividend premium). For each of these, I employ still finer variations, using means versus medians, and using equal-weighted versus market cap-weighted measures. The inventory discount is positive when the MTB for low-inventory firms exceed that for high-inventory firms. It is negative when measured using future returns, since future returns are low when current valuations (MTB) are too high and vice versa. We can also think of the difference in future returns as an inventory premium.

Figure 1 shows two measures of the inventory discount. It appears that the discount is positive for most of the late 1970s and the 1980s, turns negative in the 1990s, and begins its journey back to neutrality in the early 2000s. Another striking figure of the picture is that the two measures are reassuringly correlated. Table 3 shows the correlation coefficients among a few of these measures. It also reports Dickey-Fuller tests for unit roots, with and without time trends and lags. These tests are consistent with expectation that these series are covariance stationarity. For example, the discount cannot grow indefinitely.

The catering channel predicts that the coefficient on INVENTORY-DISCOUNT is negative. It also predicts that firms with shorter-term horizons are more sensitive to the discount. I use six pieces of executive-level information from I/B/E/S, consolidated into six firm-level indices. The greater than firm index, the shorter-term orientation. These indices are: (1) the number of executives granted options or shares ${ }^{3}$, (2) percent of options granted to employees, (3) value of unexercised exercisable options held by the average executive, (4) value realized from options for the average executive, exercised at $t+1$, (5) percentage of company stock held by employees, and (6) value of restricted stock holdings by the average executive. I then compare the inventory discount sensitivity in the top and bottom quartiles ranked by short-termism. 


\subsection{Results}

To save space, I do not report the results of regressions on each individual channel. In these regressions, I also conduct cross-sectional tests. For example, the data shows that shorter term firms tend to cater more. Details of these are at the author's website.

In Table 4, I report summary results with all channels together. Model (1) uses the differencing specification and model (2) uses the fixed effects specification. In (1), both financing and catering channels are statistically significant, but in (2), only the catering channel is significant. I interpret this as evidence that the dissipation channel is not present, and the financing channel as at best weakly present. The catering channel, however, is statistically significant in a robust way. It is also as economically significant as the fundamentals, even with the large number of regressors. For example, one standard deviation of the catering coefficient is associated with $3 \%$ standard deviation of the INVENTORY, comparable to the $5 \%$ for $q$, a proxy for FUNDAMENTALS.

In Figure 2, I show the progressive contributions of the three channels, with increasingly restricted models. The baseline specification is that for model (1) in Table 4 . Other specifications show the same conclusions. The directions of the arrows show what is being restricted, with the left-pointing ones representing restrictions on catering, upward ones for dissipation, and right-pointing ones for financing. The $p$-values of the restrictions are show on the arrows. For example, going from the bottom-most full specification to northwest represents a restriction on catering. The low $p$-value of .0003 says that catering is significantly different from zero. Further, the drop in adjusted R-squared from .647 to .603 is much larger than those going north or northeast. This shows that catering is an important explanation for 
INVENTORY. Indeed, all the north-pointing arrows have high $p$-values, suggesting that dissipation is statistically indistinguishable from zero in both unrestricted and restricted models. Also, the catering-only box at upper right has a fairly high adjusted $R$-squared of .637, consistent again with the story that catering does most of the explaining of inventory.

\subsection{Robustness and Alternative Interpretations}

I repeat the robustness checks and controls in the previous "fundamentals only" test for the channels. The result is still that the catering channel is most important, and is unreported.

Might there be alternatives to the catering story? First, I emphasize that the financing, dissipation, and catering channels are neither exhaustive nor exclusive. For example, Morck, et al. (1990) describe another hypothesis, that the stock market impacts capital expenditures via an information channel. Under this hypothesis, the stock market affects expenditures because it provides investment information useful to firms. However, even Morck, et al. (1990) dismiss this hypothesis as a lame strawman that does not need testing, because it is difficult to imagine that the stock market has better information than insiders in firms do.

Also, one set of alternative interpretations can be ruled out because of the empirics done. These have to do with explanations based on time-varying investment opportunities, financial constraints, or contracting problems such as agency and governance. These are ruled out by the tests of the "fundamentals only" hypothesis and the financing and dissipation channels, respectively. Consider, for example, the alternative story that the catering channel arise not from inefficient markets but from sales opportunities. However, since sales opportunities are part of fundamentals, I have already controlled for them in the "fundamentals only" test. Further, this story of sales opportunities is not consistent with the results obtained when 
catering to inventory premium is measured using future returns.

A more intriguing critique of the set of hypotheses is that it could be that markets are efficient and it is firms and managers who are irrational. Originally developed by Roll (1986) in the context of takeovers, the idea is that managers, even if acting in the interest of shareholders, genuinely believe (inaccurately) that their firms are undervalued. Such overconfident managers might load up on too much inventory (thinking that sales will come) or too little (thinking that they can handle the same amount of sales with less inventory). I do not test this hypothesis for several reasons. First, managers' overconfidence is much less observable (but see Malmeindier and Tate (2002)). Second, while the psychological basis of some aspects of investor sentiment (e.g., herding) has time variations and is widely documented (e.g., Baker, et al. (2004), Barberis, et al. (1998)), it is harder to think of the psychological basis of overconfidence having the same time variation. Third, the investor sentiment paradigm is comparatively more studied and accepted. Finally, the overconfidence interpretation and the market inefficiency interpretation can be discriminated by examining the impact of future returns. If markets were efficient and managers overconfident, future returns would not be especially low because of current overvaluation. In the results section, I report tests that use future returns as measures of BEHAVIORAL. The result is consistent only with a market inefficiency paradigm. Nevertheless, both the overconfidence and market inefficiency paradigms could simultaneously hold even if just the latter is observably dominant. This is a promising avenue for future research.

Finally, I have to consider if changes in inventory, unlike changes in capital expenditures studied in macroeconomics and finance, might actually not be the result of policy decisions by 
firms. Instead, they could be involuntary changes that are outcomes of changes to say, sales. What this means is that the relationship between dependant and independent variables might be hardwired. Three arguments count against this interpretation. First, I measure sales prospects, not sales. It is harder to imagine any involuntary change of inventory due to changes in sales prospects. Second, I measure inventory changes at yearly frequencies. While it is plausible, even likely, that inventory changes might not be policy decisions at shorter frequencies, it is much harder to say that firms do not review their inventory levels at yearly intervals when, for example, they and their auditors review financial statements. Even nonactions could be viewed as policy decisions at these times. The third counter-argument is that in the data, the volatility of inventory is high. For example, a ratio of standard deviation to mean can be computed for inventory change for each firm. This ratio has a mean of $34 \%$. Similarly, a ratio of standard deviation to mean can be computed for inventory/PPE. This has a mean of $51 \%$. Such high ratios suggest that it is unlikely that firms do not have an active hand in their inventory policy.

\section{Conclusion}

I find that the stock market does influence inventory decisions and provide evidence that this influence is likely to have taken effect via a catering channel, perhaps also by a financing channel, but not by a dissipation channel. If true, this result has important theoretical and practical implications.

The theoretical implications are that inventory models can no longer rely on rational models to derive costs of capital. Further, studies on the stock market and inventory cannot assume a straightforward link from the former to the latter via some cost of capital argument. Finally, 
more accurate models might be obtained by accounting for inefficient market parameters (e.g., Netessine and Roumiantsev (2005)).

The practical implication is that inventory levels might have been optimized with a shortterm view, rather than for the long-term interest of the firm. One natural line of future work is to further confirm this empirically, for example, by investigating long-term returns within a Fama and Macbeth (1973) framework. Another line of future research is to investigate the source of mis-valuation in general, and the inventory discount in particular. For example, it is possible that investors sometimes treat high inventory as a signal of operational incompetence but at other times, treat high inventory as a signal of expected growth.

In a broader sense, this paper points to interaction between financial markets and operations management. I have chosen to study a specific case, between the stock market and inventory decisions. It could be a profitable research agenda to investigate other aspects of this broader interaction. 


\section{Endnotes}

${ }^{1}$ Gaur, et al. (2005) regress inventory turn (defined as cost of goods sold over inventory) on gross margin, capital intensity, and sales surprise. To facilitate comparison with other measures here, I use the inverse of inventory turn. Also, sales surprise is a market factor likely to be confounded with BEHAVIORAL, so I drop it in the baseline regression. In any case, adding it does not qualitatively change the results.

2 The data is at http://mba.tuck.dartmouth.edu/pages/faculty/ken.french/data_library.html, for which I am grateful. Last accessed July 21, 2005.

${ }^{3}$ In I/B/E/S, "executives" mean top management officers as defined by the firm, usually taken to mean vice president and above, while "employees" mean all staff, full-time or otherwise. 


\section{References}

Abel, A., and O. Blanchard. "The Present Value of Profits and Cyclical Movements in Investment," Econometrica, 54(1986), 249-274.

Aghion, P., and J. C. Stein. Growth Vs. Margins: Destabilizing Consequences of Giving the Stock Market What It Wants, Economics Department Working Paper. Cambridge, MA: Harvard University, 2005

Baker, G. P. "Incentive Contracts and Performance Measurement," Journal of Political Economy, 100(1992), 598-614.

Baker, M., J. C. Stein, and J. Wurgler. "When Does the Market Matter? Stock Prices and the Investment of Equity-Dependent Firms," The Quarterly Journal of Economics, 118(2003), 9691005.

Baker, M., R. S. Ruback, and J. Wurgler, "Behavioral Corporate Finance: A Survey," in Eckbo, B. E. (Ed.), Handbooks in Corporate Finance: Empirical Corporate Finance, 2004

Baker, M., and J. Wurgler. "A Catering Theory of Dividends," Journal of Finance, LIX(2004).

Barberis, N., A. Shleifer, and R. Vishny. "A Model of Investor Sentiment," Journal of Financial Economics, 49(1998), 307-343.

Barberis, N., and R. Thaler, "A Survey of Behavioral Finance," in Constantinides, G. M., M. Harris and R. Stulz (Eds.), Handbook of the Economics of Finance: 1052-1090. New York: Elsevier Science B.V., 2003

Barro, R. J. "The Stock Market and Investment," Review of Financial Studies, 3(1990), 115-132.

Blanchard, O., C. Rhee, and L. H. Summers. The Stock Market, Profit, and Investment, NBER Working Paper 3370. Cambridge, MA: National Bureau of Economic Analysis, 1990

Blinder, A. S., and L. J. Maccini. "Taking Stock: A Critical Assessment of Recent Research on Inventories," Journal of Economic Perspectives, 5(1991), 73-96.

Boudreaux, K. J. "Discounts and Premiums on Closed-End Mutual Funds: A Study in Valuation," Journal of Finance, 28(1973), 515-522.

Brainard, W. C., and J. Tobin. "Pitfalls in Financial Model Building," American Economic Review 
Papers and Proceedings, 56(1968), 99-122.

Chan, K., L. K. C. Chan, N. Jegadeesh, and J. Lakonishok. Earnings Quality and Stock Returns, NBER Working Paper 8308. Cambridge, MA: NBER, 2001

Chen, H., M. Z. Frank, and O. Q. Wu. "What Actually Happened to the Inventories of American Companies between 1981 and 2000?," Management Science, Forthcoming(2005).

Daniel, K., and S. Titman. "Market Reactions to Tangible and Intangible Information," National Bureau of Economic Research, Inc, NBER Working Papers: 9743.(2003).

Dechow, P. M., R. Sloan, and A. P. Sweeney. "Detecting Earnings Management," Accounting Review, 70(1995), 193-225.

Fama, E. F., and J. D. MacBeth. "Risk, Return, and Equilibrium: Empirical Tests," Journal of Political Economy, 81(1973), 607-636.

Fama, E. F., and K. R. French. "Common Risk Factors in the Returns on Stock and Bonds," Journal of Financial Economics, 33(1993), 3-56.

Fischer, S., and R. C. Merton. "Macroeconomics and Finance: The Role of the Stock Market," Carnegie-Rochester Conference Series on Public Policy, 21(1984), 57-108.

Gaur, V., M. Fisher, and A. Raman. "An Econometric Analysis of Inventory Turnover Performance in Retail Services," Management Science, 51(2005), 181 ?94.

Gompers, P., J. Ishii, and A. Metrick. "Corporate Governance and Equity Prices," The Quarterly Journal of Economics, 118(2003), 107-155.

Holmstrom, B. "Managerial Incentive Problems - a Dynamic Perspective," Review of Economic Studies, 66(1999), 169-182.

Jensen, M. "Agency Costs of Free Cash Flow, Corporate Finance, and Takeovers," American Economic Review, 76(1986), 323-329.

Jones, J. "Earnings Management During Import Relief Investigation," Journal of Accounting Research, 29(1991), 193-228.

Kaplan, S. N., and L. Zingales. "Do Investment-Cash Flow Sensitivities Provide Useful Measures of Financing Constraints," The Quarterly Journal of Economics, 112(1997), 169-215.

Kashyap, A., O. Lamont, and J. C. Stein. "Credit Conditions and the Cyclical Behavior of 
Inventories," Quarterly Journal of Economics, 109(1994), 565-592.

Lai, R. Inventory Signals, Harvard NOM Working Paper No. 05-15. Boston, MA, 2005

Lee, C. M. C., A. Shleifer, and R. H. Thaler. "Investor Sentiment and the Closed-End Fund Puzzle," Journal of Finance, 46(1991), 75-109.

Long, J. B. D., A. Shleifer, L. H. Summers, and R. J. Waldmann. "Noise Trader Risk in Financial Markets," Journal of Political Economy, 98(1990), 703-738.

Maines, L., and J. Hand. "Individuals' Perceptions and Misperceptions of the Time Series Properties of Quarterly Earnings," Accounting Review, 71(1996), 317-339.

Malmeindier, U., and G. Tate. Ceo Overconfidence and Corporate Investment, Economics Department Working Paper. Cambridge, MA: Harvard University, 2002

Morck, R., A. Shleifer, and R. Vishny. "The Stock Market and Investment: Is the Market a Sideshow?," Brookings Papers on Economic Activity, 2(1990), 157-215.

Narayanan, M. P. "Managerial Incentives for Short-Term Results," Journal of Finance, 40(1985), 1469-1484.

Neal, R., and S. M. Wheatley. "Do Measures of Investor Sentiment Predict Returns?," Journal of Financial \& Quantitative Analysis, 33(1998), 523-547.

Netessine, S., and S. Roumiantsev. Empirical Testing of Classical Inventory Management Models: Evidence from Us Public Companies. Paper presented at the POMS OM Frontiers: Winds of Change, Chicago, 2005.

Polk, C., and P. Sapienza. The Real Effects of Investor Sentiment: Northwestern University, 2004

Poterba, J. "The Stock Market and Investment: Is the Market a Sideshow? Discussion," Brookings Papers on Economic Activity, 2(1990), 208-212.

Roll, R. "On Computing Mean Returns and the Small Firm Premium," Journal of Financial Economics, 12(1983), 371-386.

---. "The Hubris Hypothesis of Corporate Takeovers," Journal of Business, 59(1986), 197-216.

Scharfstein, D. S., and J. C. Stein. "Herd Behavior and Investment," American Economic Review, 80(1990), 465-479.

Shleifer, A. Inefficient Markets. Oxford, Oxford University Press, 2000 
Sloan, R. "Do Stock Prices Reflect Information in Accruals and Cash Flows About Future Earnings?," Accounting Review, 71(1996), 289-315.

Stein, J. C. "Takeover Threats and Managerial Myopia," Journal of Political Economy, 96(1988), 6180.

---. "Rational Capital Budgeting in an Irrational World," Journal of Business, 1996(1996), 429-455.

Summers, L. H. "Taxation and Corporate Investment: A Q-Theory Approach," Brookings Papers on Economic Activity, 1(1981), 67-127.

Teoh, S. H., I. Welch, and T. J. Wong. "Earnings Management and the Long-Run Market Performance of Initial Public Offerings," Journal of Finance, 53(1998), 1935-1974.

Tobin, J. "A General Equilibrium Approach to Monetary Theory," Journal of Money Credit and Banking, 1(1969), 15-29.

Whitin, T. M. "Inventory Control in Theory and Practice," Quarterly Journal of Economics, 66(1952), 502-521.

Zweig, M. E. "An Investor Expectations Stock Price Predictive Model Using Closed-End Fund Premiums," Journal of Finance, 28(1973), 67-87. 


\section{Figure 1 - The Inventory Discount.}

The vertical axis is a normalized scale obtained by subtracting the raw discount by the mean over the entire time series, and dividing that by the standard deviation of the time series. The lighter line is the discount calculated as the difference in mean market-to-book value between the lowest- and highest-inventory quartiles classified by inventory value. The darker line shows the negative of the discount calculated as the mean future three-year stock return of the lowest- and highest-inventory quartiles, also classified by inventory value.

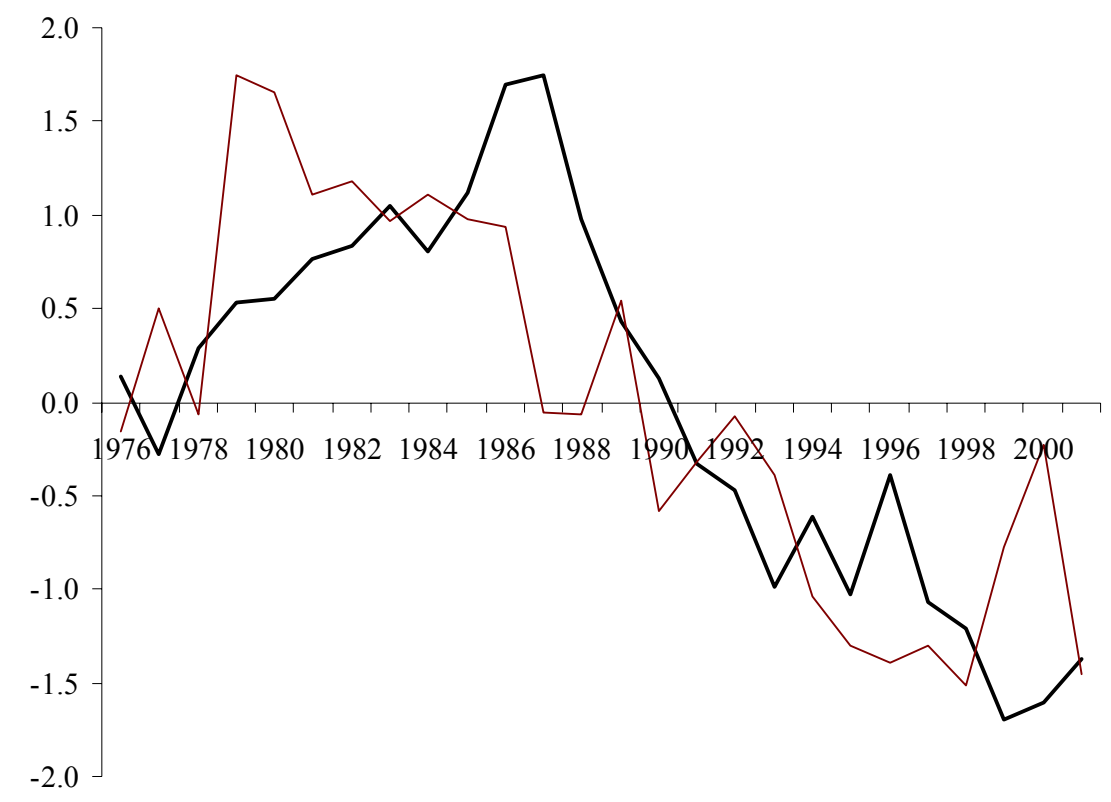


Figure 2 - Contributions by the Three Channels

The bottom-most box has the complete specification is as in Table 4 .

INVENTORY $Y_{i t}=\beta_{0}+\beta_{1}$. FUNDAMENTALS $i t+\gamma_{1}$. EQUITY $_{i, t-1}+\gamma_{2} . D E B T_{i, t-1}+\beta_{2}$. BEHAVIORALi,t-1 + $\beta_{3} . B E H A V I O R A L^{2} i, t-1+\zeta_{1} G_{i t}+\zeta_{2} . B E H A V I O R A L^{2} i, t-1 \times G_{i t}+\eta . I N V E N T O R Y-D I S C O U N T_{i t}+\varepsilon_{i t}$.

The higher boxes place restrictions on the financing, catering, and dissipation variables.

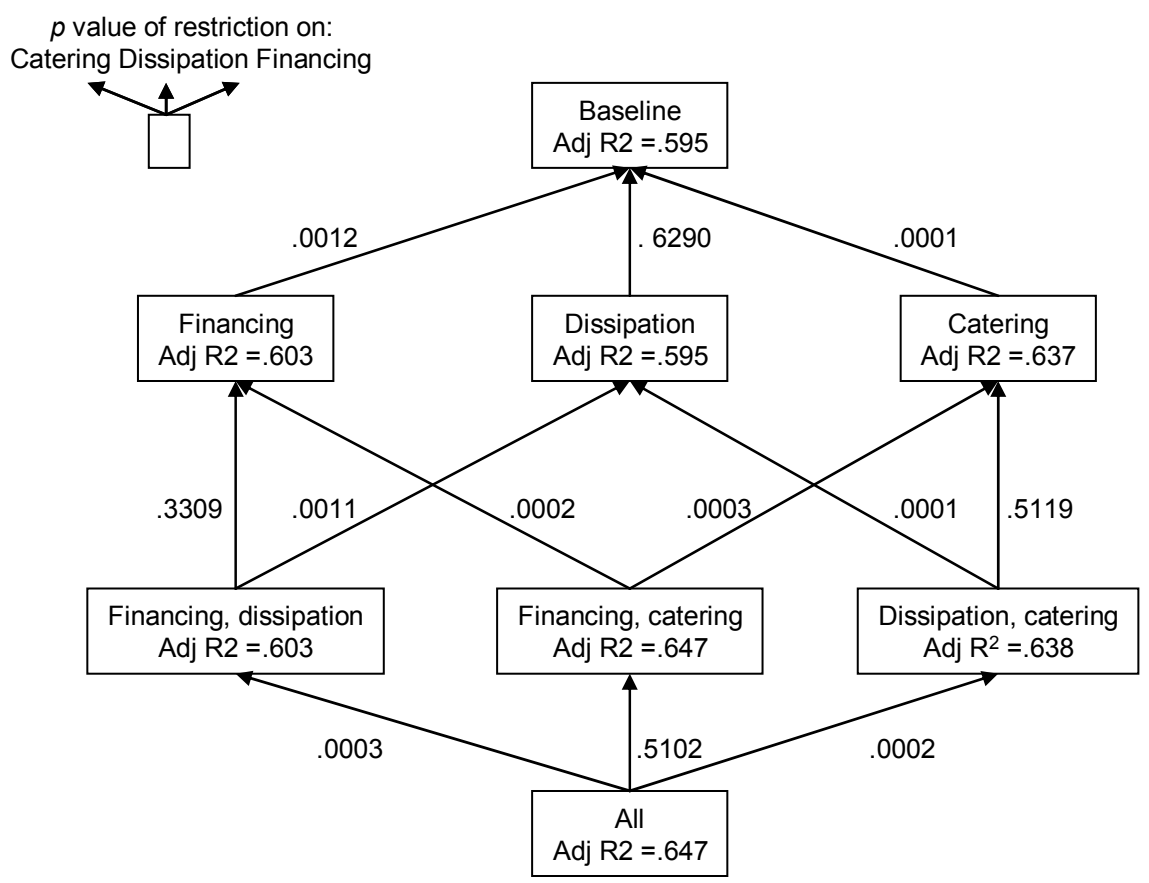




\section{Table 1 - Summary Statistics}

The data is from COMPUSTAT-CRSP, I/B/E/S, and ExecuComp, winsorized at 1\% and 99\%. Observations cannot be involved in acquisitions or mergers, the market-to-book and Q must be between 0.1 and 100, sales, assets, capital expenditures, income before earnings and interest, common dividends, common equity must all be non-negative.

Year

Market cap

Book equity

Market-to-book ratio

Return (\%)

$\Delta$ cash flow

$\Delta$ sales

$\Delta$ inventory

Alpha CAPM

Alpha Fama French

Inventoryt / PPEt-1

Discretionary accruals

$\Delta$ debt

$\Delta$ equity

$\mathrm{KZ}$ index

$q$

G index

Restricted stock holdings by average executive (\$)

Unexercised exercisable options held by average executive (\$)

$\$$ realized from options for average executive, exercised

$\%$ company stock held by employees

$\%$ options granted to employees

Number of executives granted options or shares

\begin{tabular}{|c|c|c|c|c|}
\hline$N$ & Mean & SD & Min. & Max \\
\hline 97929 & 1989.7 & 8.5 & 1962 & 2003 \\
\hline 97917 & 885.8 & 6630.1 & 0.0 & 508329.5 \\
\hline 97806 & 406.1 & 2388.1 & -4174.0 & 186066.5 \\
\hline 97917 & 3.0 & 5.9 & 0.0 & 99.4 \\
\hline 71057 & 3.2 & 29.1 & 0.0 & 4474.1 \\
\hline 97917 & 4.4 & 5.9 & -12.2 & 12.9 \\
\hline 97917 & 1.7 & 1.1 & 0.2 & 3.3 \\
\hline 97917 & 2.1 & 1.2 & 0.0 & 3.4 \\
\hline 71057 & 1.8 & 29.0 & -2.4 & 4471.8 \\
\hline 71057 & 1.7 & 29.0 & -4.6 & 4469.3 \\
\hline 97929 & 8.7 & 10.9 & 0.0 & 24.1 \\
\hline 4512 & -40.5 & 2808.0 & -188518.8 & 5081.5 \\
\hline 97929 & 3.7 & 4.2 & -1.0 & 8.6 \\
\hline 97929 & 1.2 & 1.8 & -0.8 & 4.0 \\
\hline 97929 & -1.3 & 15.7 & -137.4 & 6.3 \\
\hline 97917 & 1.7 & 2.3 & 0.0 & 85.4 \\
\hline 3435 & 8.8 & 2.8 & 1.0 & 17.0 \\
\hline 8908 & 411.5 & 7436.4 & 0.0 & 655968.8 \\
\hline 8908 & 2114.2 & 9080.8 & 0.0 & 556283.0 \\
\hline 6571 & 600.6 & 2970.6 & 0.0 & 121427.3 \\
\hline 5515 & 5.6 & 8.6 & 0.0 & 64.2 \\
\hline 10006 & 19.5 & 20.7 & 0.0 & 342.5 \\
\hline 10006 & 5.5 & 2.0 & 1.0 & 12.0 \\
\hline
\end{tabular}


Table 2 - Testing the "Fundamentals Only" Hypothesis

INVENTORY, BEHAVIORAL, and FUNDAMENTALS are measured using a variety of variables in the models below. The specification is of the form:

INVENTORY $Y_{i t}=\beta_{0}+\beta_{1}$.FUNDAMENTALS $i t+\beta_{2}$. BEHAVIORALi,t-1 + firm effects + year effects $+\varepsilon_{i t}$,

where $i$ and $t$ index firms and years. Models (1) and (2) use OLS on changes, (3) and (4) use firm fixed effects, (5) logistic, (6) uses two-stage least squares with instrumental variables, and (7) a Heckman correction. Accruals are discretionary ones, obtained by subtracting from total accruals the discretionary portion. Totals are:

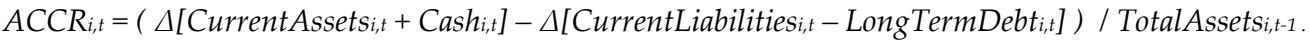

The discretionary portion is:

$$
\begin{aligned}
& \text { NONDIS-ACCR } \left.i_{i, t}=\hat{\theta}_{0}+\hat{\theta}_{1} .(1 / \text { TotalAssets }, t-1)\right)+\hat{\theta}_{2 .}(\Delta \text { sales } i, t-\text { AaccountsReceivable } i, t) / \text { TotalAssets }, t-1+
\end{aligned}
$$

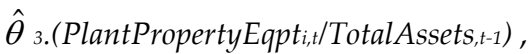

where the $\hat{\theta}$ 's are obtained from firm-by-firm regressions using all four-digit SIC code peers (i.e., all but itself):

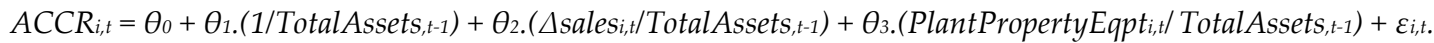

Most data is from COMPUSTAT-CRSP and I/B/E/S, winsorized at $1 \%$ and $99 \%$. The closed-end fund discount is from Neal and Wheatley (1998) (for years 1962 through 1993), CDA (1994 through 1998), and The Wall Street Journal end-ofyear issues (1999 through 2000). Fama-French factors are SML, HML, and MOM, from Professor French's website. The Heckman correction in model (7) uses the following selection model:

$$
\text { SELECTED }=f(M K T C A P, S \mathcal{E} \text { P500, ASSETS }) \text {, }
$$

where MKTCAP is market capitalization, SEP500 is whether the firm is ever in the S\&P 500, and ASSETS is total assets. Observations cannot be involved in acquisitions or mergers, the market-to-book and Q must be between 0.1 and 100, sales, assets, capital expenditures, income before earnings and interest, common dividends, common equity must all have non-negative values. Estimations are done with heteroskedastic-robust standard errors (in brackets

\begin{tabular}{|c|c|c|c|c|c|c|c|}
\hline INVENTORY & $\begin{array}{l}(1) \\
\Delta \text { inventory }\end{array}$ & $\begin{array}{l}(2) \\
\Delta \text { inventory }\end{array}$ & $\begin{array}{l}\text { (3) } \\
\text { Inventory/PPE }\end{array}$ & $\begin{array}{l}\text { (4) } \\
\text { Inventory/PPE }\end{array}$ & $\begin{array}{l}5) \\
\text { Inventory } \\
\text { dummy } \\
\end{array}$ & $\begin{array}{l}\text { (6) } \\
\Delta \text { inventory }\end{array}$ & $\begin{array}{l}\text { (7) } \\
\Delta \text { inventory }\end{array}$ \\
\hline \multicolumn{8}{|l|}{ BEHAVIORAL } \\
\hline CAPM alphat-1 & $\begin{array}{l}.0350 \\
(.0004)\end{array}$ & $\begin{array}{l}.0020 \\
(.0003)\end{array}$ & & & $\begin{array}{l}.0075 \\
(.0007)\end{array}$ & & $\begin{array}{l}.004 \\
(.000)\end{array}$ \\
\hline Accrualst-1 & & & $\begin{array}{l}.019 \\
(.006)\end{array}$ & & & & \\
\hline $\begin{array}{l}\text { Closed-end fund } \\
\text { discountt-1 }\end{array}$ & & & & $\begin{array}{l}-.010 \\
(.006)\end{array}$ & & & \\
\hline $\begin{array}{l}\text { Fama-French alphat-1 } \\
\text { instrumented using } \\
\text { all three above }\end{array}$ & & & & & & $\begin{array}{l}.0013 \\
(.0004)\end{array}$ & \\
\hline \multicolumn{8}{|l|}{ FUNDAMENTALS } \\
\hline$\Delta$ Cash flow & & $\begin{array}{l}.058 \\
(.002)\end{array}$ & & & $\begin{array}{l}.110 \\
(.004)\end{array}$ & $\begin{array}{l}.046 \\
(.003)\end{array}$ & $\begin{array}{l}.049 \\
(.005)\end{array}$ \\
\hline$\Delta$ Sales & & $\begin{array}{l}.493 \\
(.010)\end{array}$ & & & $\begin{array}{l}1.380 \\
(.027)\end{array}$ & $\begin{array}{l}.404 \\
(.012)\end{array}$ & $\begin{array}{l}.715 \\
(.028)\end{array}$ \\
\hline$q_{\mathrm{t}-1}$ & & & $\begin{array}{l}.035 \\
(.015)\end{array}$ & $\begin{array}{l}.026 \\
(.013)\end{array}$ & & & \\
\hline Inverse Mill's ratio & & & & & & & $\begin{array}{l}-.543 \\
(.309) \\
\end{array}$ \\
\hline $\begin{array}{l}\text { Firm fixed effects } \\
\text { Year effects }\end{array}$ & Yes & Yes & $\begin{array}{l}\text { Yes } \\
\text { Yes }\end{array}$ & $\begin{array}{l}\text { Yes } \\
\text { Yes }\end{array}$ & Yes & Yes & Yes \\
\hline Adjusted $R$-squared & .244 & .513 & .838 & .837 & .294 & .082 & $\begin{array}{l}41257 \\
\text { (Wald) }\end{array}$ \\
\hline$N$ & 97,917 & 97,917 & 71,387 & 66,199 & 95,321 & 66,199 & 97,917 \\
\hline
\end{tabular}
below) and clustered around firms to minimize serial correlation. 


\section{Table 3 - Statistics for Some Measures of Inventory Discount}

The measures of inventory discount are based on the difference in the second column (e.g., future return at time $t+3$, or from $t+1$ to $t+3$, or market to book, MTB) of the low vs. high quartiles of firm-year observations, sorted by the criteria in the third column. The data is from COMPUSTAT-CRSP.

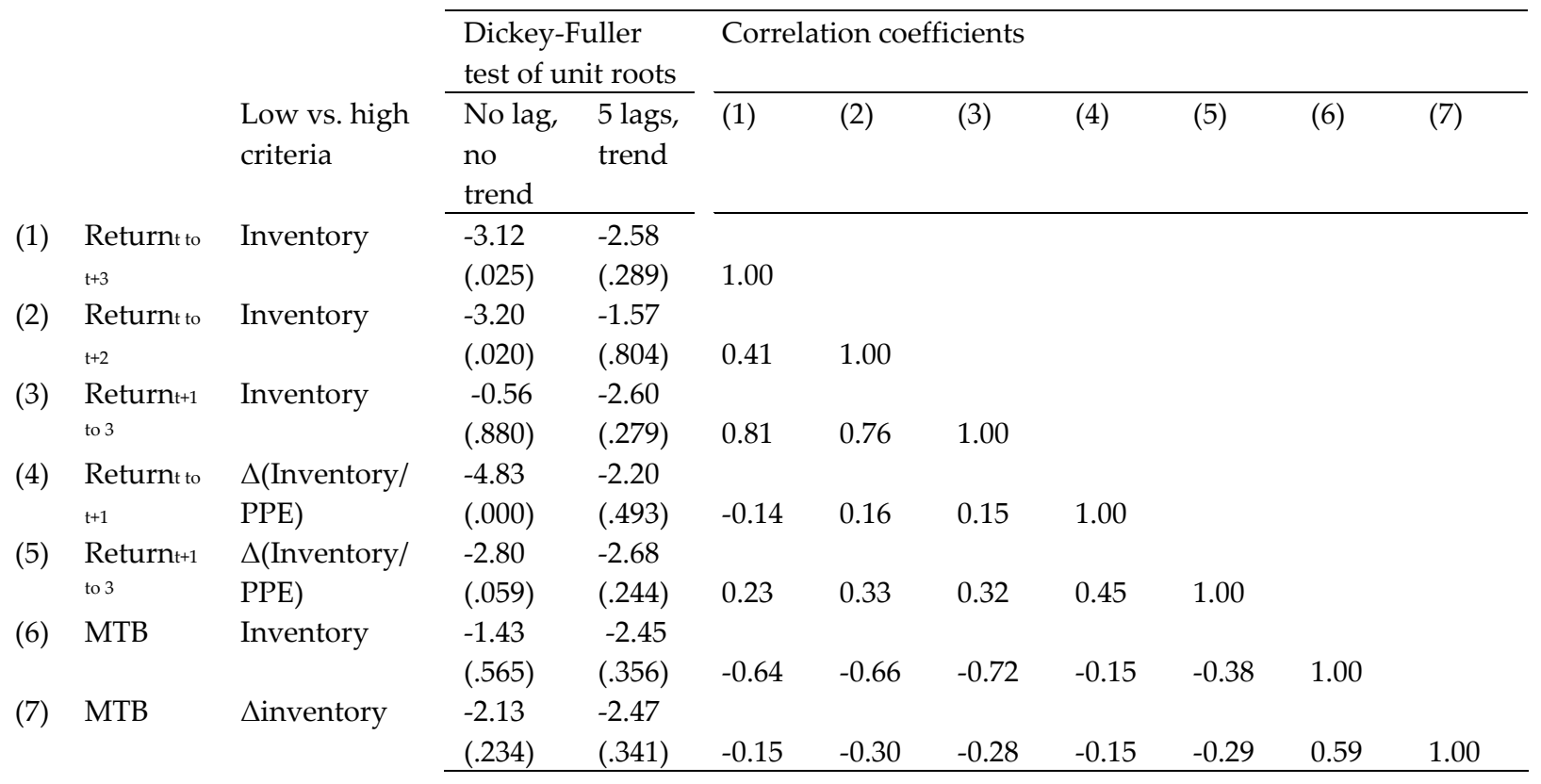




\section{Table 4 - Comparison of All Hypotheses}

The specification is:

$$
\begin{aligned}
& I_{N V E N T O R} Y_{i t}=\beta_{0}+\beta_{1} . \text { FUNDAMENTALS } i t+\gamma_{1} . E_{\text {EUITY }} \gamma_{i, t-1}+\gamma_{2} . D_{E B T_{i, t-1}+} \\
& \delta_{1 . E Q U I T Y} Y_{i, t-1} \times \text { FINANCIALLY-CONSTRAINED } D_{i t}+\delta_{2} . D E B T_{i, t-1} \times \text { FINANCIALLY-CONSTRAINED }_{i t}+ \\
& \beta_{2} \text {.BEHAVIORALi,t-1 + } \beta_{3} . \text { BEHAVIORAL }{ }^{2}, t-1+ \\
& \zeta_{1} G_{i t}+\zeta_{2} . B E H A V I O R A L^{2}{ }_{i, t-1} \times G_{i t}+\eta . I N V E N T O R Y-D I S C O U N T_{i t}+\varepsilon i t .
\end{aligned}
$$

Model (1) uses OLS on changes, and measures BEHAVIORAL with alpha CAPM and FUNDAMENTALS with sales

\begin{tabular}{|c|c|c|}
\hline INVENTORY & $\begin{array}{c}(1) \\
\Delta \text { inventory }\end{array}$ & $\begin{array}{c}(2) \\
\text { Inventory/PPE }\end{array}$ \\
\hline FINANCING & & \\
\hline$\Delta$ debt $\times \mathrm{KZ}$ & $.007(.005)$ & \\
\hline$\Delta$ equity $\times \mathrm{KZ}$ & $.017(.004)$ & \\
\hline Debt $\times \mathrm{KZ}$ & & $.00003(.00008)$ \\
\hline Daniel-Titman (DT) equity $\times \mathrm{KZ}$ & & $-.00054(.00267)$ \\
\hline DISSIPATION & & \\
\hline G index $\times$ BEHAVIORAL & $-.006(.006)$ & $.027(.032)$ \\
\hline G index $\times$ BEHAVIORAL squared & $.0002(.0001)$ & $-.001(.001)$ \\
\hline $\begin{array}{l}\text { CATERING }- \text { inventory discount/premium based on: } \\
t+1 \text { to } t+3 \text { return differences of low vs. high inventory quartiles } \\
t+1 \text { to } t+3 \text { return differences of low vs. high } \Delta \text { (inventory/PPE) } \\
\text { quartiles }\end{array}$ & $.089(.024)$ & $.215(.138)$ \\
\hline Firm fixed effects & & Yes \\
\hline Adjusted $R$-squared & .647 & .885 \\
\hline$N$ & 2,550 & 1,920 \\
\hline
\end{tabular}
and cash flow growth. Model (2) uses fixed effects, and measures BEHAVIORAL with CAPM alpha and FUNDAMENTALS with lagged $q$. Estimations are done with heteroskedastic-robust standard errors and clustered around firms to minimize serial correlation. 


\section{Inventory and the Stock Market}

Supporting Appendix for Reference Only (on-line supplement)

\section{Tests of Individual Channels}

Table A1 shows the test for the financing channel. Model (1) is a baseline to follow the specification in Morck, et al. (1990). All the coefficients are signed as predicted, and are significant. Firms that issue $1 \%$ more new debt show $6.6 \%$ more inventory growth, on average and controlling for fundamentals. This is higher but of the same order of magnitude as the 1.75\% Morck, et al. (1990) obtain for growth in capital expenditures. Similarly, firms that increase their shares by $1 \%$ show $2.5 \%$ more inventory growth. Again, this is comparable to the 1.6\% obtained by Morck, et al. (1990). Comparing this model (1) with model (1) in Table 2, we can see that FINANCING reduces the impact of BEHAVIORAL slightly, although the latter is still significant. I interpret this as weak support for the financing channel. Model (2) shows the same, using discretized versions of $\Delta$ debt and $\Delta$ equity following Morck, et al. (1990), in which they set the debt dummy to 1 if the change is more than $20 \%$ and the equity dummy to 1 if more than $10 \%$. The results are qualitatively unchanged.

Model (3) shows the delineation of the financing effect by the degree of financial constraint. As expected, constrained firms (high $\mathrm{KZ}$ index) have lower inventory levels. More interesting, the interaction of the financing channel in overvaluation (as measured by changes in debt and equity issues, after partialling out FUNDAMENTALS) with the $\mathrm{KZ}$ index is positive and significant. This again supports the financing channel: the more constrained a firm, the more it leverages misevaluation to obtain easier financing for inventory. Unreported robustness checks 
with other measures of BEHAVIORAL such as Fama-French alphas and accruals produce the same result, although the effect of FINANCIALLY-CONSTRAINED is much reduced with accruals. I interpret this as accruals picking up financial-constraints, so using accruals is less interesting as a measure of BEHAVIORAL here.

Model (4) uses the closed-end fund discount as a measure of BEHAVIORAL and DT equity. It produces negative coefficients for the FINANCING variables. These are the opposite of what is predicted, although their low economic significance (e.g., one standard deviation change in DT equity produces only $0.6 \%$ standard deviation change in INVENTORY) might be interpreted as negligible impact. The interactions with the $\mathrm{KZ}$ index obtain the predicted positive signs on the interaction terms. The economic significance is low.

It is possible that firms have different financing technologies. For example, if INVENTORY is concave in EQUITY or DEBT, and financially-constrained firms tend to also have low EQUITY or DEBT, then I would observe that these firms have a higher inventory sensitivity to finance. To take care of this, I use quadratic formulations of EQUITY and DEBT, and it turns out (in unreported regressions) that this is not a concern. Overall, I conclude that I cannot reject the financing channel, although the evidence for it is rather weak.

In Table A2, I report the results of testing the dissipation channel. In Model (1), I report a predicted quadratic relationship between INVENTORY and BEHAVIORAL, which is statistically and economically significant. In Model (2), I conduct a further test to see if the quadratic relationship is ameliorated with stronger governance. Unfortunately, the small number of observations with a $\mathrm{G}$ index does not produce a statistically valid estimation. Nevertheless, the $\mathrm{G}$ index is negatively signed and significant, consistent with the view that stronger governance 
reduces inventory, controlling for other effects. In Model 3, I estimate with a fixed-effects specification using the closed-end fund discount measure of BEHAVIORAL. The dissipation effect is not evident, as the only significant coefficient on BEHAVIORAL is on the linear term. Model (4) attempts to use the G index, and again, due to the small sample size, I could not arrive at a reasonable estimation. Overall, it appears that the dissipation effect is only very weakly supported, if at all.

In Table A3, I report the test for the catering channel. Panel (a) shows the influence of INVENTORY-DISCOUNT and panel (b) shows how this influence is different for firms with more short-term orientation $(\mathrm{S})$ versus others ( $\mathrm{L}$, for long-term orientation), measured in various ways. In panel (a), the first five models are estimated using inventory growth as the measure of INVENTORY and five different measures of INVENTORY-DISCOUNT (other measures described earlier are unreported but achieve the same qualitative result). As predicted, the measures using differences in future returns (which can be thought of as inventory premium) are positively signed, while the last using the difference in market-to-book between high- and low-inventory firms shows the predicted negative sign. All coefficients are significant. For illustration, I show a model based on inventory/PPE as a measure of INVENTORY. The result is qualitatively similar. Panel (b) shows just the coefficients for INVENTORY-DISCOUNT, from estimations done with specifications like those of model (6) in panel (a). Each of the six sub-panels is for some measure of short-term orientation of the management. For example, sub-panel (1) classifies firm-years by the number of executives in that firm-year that hold options on the firm's stock. The top quartile of these firm-years is considered short-term and the bottom quartile long-term. As predicted, coefficients on 
INVENTORY-DISCOUNT is almost always more sensitive for short-term oriented firm-years, while they are mostly lower or statistically indistinguishable from zero for long-term oriented firm-years. A particularly strong cross-sectional test is model (4), which shows catering in the current period stronger among firms whose executives exercise their options in the next period. 


\section{Table A1 - Testing the Financing Channel}

Models (1) and (2) use the following specification:

$$
\begin{aligned}
& \text { INVENTOR }_{i t}=\beta_{0}+\beta_{1} . \text { FUNDAMENTALS } i t+\beta_{2} . \text { BEHAVIORALit-1 }+ \\
& \gamma_{1} . \text { EQUITY } Y_{i, t-1}+\gamma_{2} . D E B T_{i, t-1}+\text { firm effects }^{+} \text {year effects }+\varepsilon i t .,
\end{aligned}
$$

while models (3) and (4) add cross-sectional financial constraints:

INVENTORY $Y_{i t}=\beta_{0}+\ldots$ as before $\ldots+\gamma_{1}$. EQUITY $_{i, t-1}+\gamma_{2}$. DEBT $_{i, t-1}+\delta_{1}$. EQUITY $_{i, t-1} \times$ FINANCIALLY-CONSTRAINED $_{i t}+$ $\delta_{2 . D E B T}, t-1 \times$ FINANCIALLY-CONSTRAINED ${ }_{i t}+$ firm effects + year effects $+\varepsilon i t$.

Models (1) through (3) use OLS on changes and (4), firm fixed effects. The data is from COMPUSTAT-CRSP and I/B/E/S, winsorized at 1\% and 99\%. The closed-end fund discount is from Neal and Wheatley (1998) (1962 through 1993), CDA (1994 through 1998), and The Wall Street Journal (1999 through 2000). The discretized versions of $\Delta$ debt is set to 1 if $\Delta$ debt is more than $20 \%$; likewise for equity if more than $10 \%$. The measure of DT equity is $\log \left(M_{t} / M_{t-\tau}\right)-$ $r(t-\tau, t)$, where $M_{t}$ is the per share value at $t$ and $r(t-\tau, t)$ is the $\log$ stock return from $t-\tau$ to $t$, in turn defined as $r(t-\tau, t)=$ $\sum_{s=t-\tau+1}^{t} \log \left[\left(M_{s .} f_{s}+D_{s}\right) / M_{s-1}\right]$, where $f_{s}$ is the price adjustment factor from $s-1$ to $s$ that accounts for splits and rights issues, and $D_{s}$ is the per-share cash distribution paid at time $s$. The $\mathrm{KZ}$ index is $-1.001909^{*}$ [(Income before extraordinary items + Depreciation \& amortization)/PPE $]+0.2826389^{*}[$ (Assets + Market capitalization - Common equity - Deferred taxes) / Assets $]+3.139193^{*}$ [(Long-term debt + Debt in current liabilities) / (Long-term debt + Debt in current liabilities + Stockholders' equity) $-39.3678^{*}[($ Common dividends + Preferred dividends) / PPE $]-$

$1.314759^{*}$ [Cash \& short-term investments / PPE]. Observations cannot be involved in acquisitions or mergers, the market-to-book and Q must be between 0.1 and 100, sales, assets, capital expenditures, income before earnings and interest, common dividends, common equity must be non-negative. Estimations are with heteroskedastic-robust

\begin{tabular}{|c|c|c|c|c|}
\hline INVENTORY & $\begin{array}{l}(1) \\
\Delta \text { inventory }\end{array}$ & $\begin{array}{l}(2) \\
\Delta \text { inventory }\end{array}$ & $\begin{array}{l}(3) \\
\Delta \text { inventory }\end{array}$ & $\begin{array}{l}(4) \\
\text { Inventory/PPE }\end{array}$ \\
\hline \multicolumn{5}{|l|}{ BEHAVIORAL } \\
\hline CAPM alphat-1 & $.0010(.0003)$ & $.0020(.0003)$ & $.0014(.0003)$ & \\
\hline Closed-end fund discountt- 1 & & & & $-.009(.006)$ \\
\hline \multicolumn{5}{|l|}{ FUNDAMENTALS } \\
\hline$\Delta$ Cash flow & $.048(.002)$ & $.055(.002)$ & $.024(.002)$ & \\
\hline$\Delta$ Sales & $.332(.011)$ & $.404(.010)$ & $.297(.000)$ & \\
\hline$q_{\mathrm{t}-1}$ & & & & $.019(.012)$ \\
\hline \multicolumn{5}{|l|}{ FINANCING } \\
\hline$\Delta$ debt & $.066(003)$ & & $.033(.003)$ & \\
\hline$\Delta$ equity & $.025(.006)$ & & $.034(.006)$ & \\
\hline$\Delta$ debt dummy & & $.417(.014)$ & & \\
\hline$\Delta$ equity dummy & & $.018(.008)$ & & \\
\hline Debt & & & & $-.0001(.0001)$ \\
\hline Daniel-Titman (DT) equity & & & & $-.044(.009)$ \\
\hline Kaplan-Zingales (KZ) index & & & $-.007(.001)$ & $-.016(.004)$ \\
\hline$\Delta$ debt $\times \mathrm{KZ}$ index & & & $.011(.001)$ & \\
\hline$\Delta$ equity $\times \mathrm{KZ}$ index & & & $.022(.001)$ & \\
\hline Debt $\times \mathrm{KZ}$ index & & & & $.0004(.0001)$ \\
\hline DT equity $\times \mathrm{KZ}$ index & & & & $.0029(.0006)$ \\
\hline Firm fixed effects & & & & Yes \\
\hline Year effects & Yes & Yes & Yes & Yes \\
\hline Adj $R$-squared & .543 & .534 & .565 & .840 \\
\hline$N$ & 97,917 & 97,917 & 97,917 & 66,199 \\
\hline
\end{tabular}
standard errors (in brackets) and clustered around firms to minimize serial correlation. Model (4) has 2 lags. 


\section{Table A2 - Testing the Dissipation Channel}

The specification for models (1) and (3) is:

INVENTOR $Y_{t}=\beta_{0}+\beta_{1}$. FUNDAMENTALS $S_{t}+\beta_{2} . B E H A V I O R A L t-1+\beta_{3} . B E H A V I O R A L^{2} t-1+\varepsilon t$.

That for models (2) and (4) is:

$$
\begin{aligned}
& \text { INVENTOR } Y_{t}=\beta_{0}+\beta_{1} . \text { FUNDAMENTALS } S_{t}+\beta_{2} . \text { BEHAVIORALt-1 + } \\
& \text { 3.BEHAVIORAL }{ }^{2} t-1+\zeta_{1} G_{t}+\zeta_{2} \text {.BEHAVIORAL }{ }^{2}{ }_{t-1} \times G_{t}+\varepsilon t .
\end{aligned}
$$

Models (1) and (2) use OLS on changes and (3) and (5), firm fixed effects. Most data is from COMPUSTAT-CRSP and I/B/E/S, winsorized at 1\% and 99\%. The closed-end fund discount is from Neal and Wheatley (1998) (for years 1962 through 1993), CDA (1994 through 1998), and The Wall Street Journal end-of-year issues (1999 through 2000). The governance index $\mathrm{G}$ is from Gompers, et al. (2003), obtained from I/B/E/S. Observations cannot be involved in acquisitions or mergers, the market-to-book and Q must be between 0.1 and 100, sales, assets, capital expenditures, income before earnings and interest, common dividends, common equity must all have non-negative values.

Estimations are done with heteroskedastic-robust standard errors (in brackets below) and clustered around firms to

\begin{tabular}{|c|c|c|c|c|}
\hline INVENTORY & $\begin{array}{l}\text { (1) } \\
\Delta \text { inventory }\end{array}$ & $\begin{array}{l}(2) \\
\Delta \text { inventory }\end{array}$ & $\begin{array}{l}\text { (3) } \\
\text { Inventory/PPE }\end{array}$ & $\begin{array}{l}\text { (4) } \\
\text { Inventory/PPE }\end{array}$ \\
\hline \multicolumn{5}{|l|}{ BEHAVIORAL } \\
\hline CAPM alphat-1 & $\begin{array}{l}-.035 \\
(.004)\end{array}$ & $\begin{array}{l}.045 \\
(.067)\end{array}$ & & \\
\hline CAPM alpha ${ }^{2}-1$ & $\begin{array}{l}.0012 \\
(.0001)\end{array}$ & $\begin{array}{l}-.001 \\
(.002)\end{array}$ & & \\
\hline Closed-end fund discount-1 & & & $\begin{array}{l}.027 \\
(.016)\end{array}$ & $\begin{array}{l}.057 \\
(.210)\end{array}$ \\
\hline Closed-end fund discount $t^{2}-1$ & & & $\begin{array}{l}.000007 \\
(.00057)\end{array}$ & $\begin{array}{l}-.012 \\
(.018)\end{array}$ \\
\hline \multicolumn{5}{|l|}{ FUNDAMENTALS } \\
\hline$\Delta$ Cash flow & $\begin{array}{l}.058 \\
(.002)\end{array}$ & $\begin{array}{l}.043 \\
(.009)\end{array}$ & & \\
\hline$\Delta$ Sales & $\begin{array}{l}.490 \\
(.010)\end{array}$ & $\begin{array}{l}.642 \\
(.048)\end{array}$ & & \\
\hline$q_{\mathrm{t}-1}$ & & & $\begin{array}{l}.026 \\
(.013) \\
\end{array}$ & $\begin{array}{l}-.119 \\
(.209) \\
\end{array}$ \\
\hline \multicolumn{5}{|l|}{ GOVERNANCE } \\
\hline G index & & $\begin{array}{l}-.020 \\
(.009)\end{array}$ & & $\begin{array}{l}.018 \\
(.102)\end{array}$ \\
\hline $\mathrm{G}$ index $\times$ BEHAVIORAL & & $\begin{array}{l}-.006 \\
(.007)\end{array}$ & & $\begin{array}{l}-.021 \\
(.025)\end{array}$ \\
\hline G index $\times$ BEHAVIORAL $^{2}$ & & $\begin{array}{l}.0002 \\
(.0002)\end{array}$ & & $\begin{array}{l}.003 \\
(.002)\end{array}$ \\
\hline Firm fixed effects & & & Yes & Yes \\
\hline Year effects & Yes & Yes & Yes & Yes \\
\hline Adj $R$-squared & .514 & .584 & .837 & .884 \\
\hline$N$ & 97,917 & 3,435 & 66,203 & 1,920 \\
\hline
\end{tabular}
minimize serial correlation. Models (3) and (4) have two lags. 


\section{Table A3 - Testing the Catering Channel}

Panel (a) shows a regression of INVENTORY on various measures of BEHAVIORAL, FUNDAMENTALS, and INVENTORY-DISCOUNT. The measures of inventory discount are based on the difference (such as the future return at time $t+3$ or market to book, MTB) of the low vs. high quartiles of firm-year observations, sorted by certain criteria (such as inventory, or $\triangle$ inventory/PPE). Panel (b) shows just the coefficients for INVENTORY-DISCOUNT, from estimations done with specifications like those of models (9) and (10) in panel (a). Each of the six sub-panels is for some measure of short-term orientation of the management. For example, sub-panel (1) classifies firm-years by the number of executives in that firm-year that hold options on the firm's stock. The top quartile of these firm-years is considered short-term and the bottom quartile long-term. Most data is from COMPUSTAT-CRSP and I/B/E/S, winsorized at 1\% and 99\%. The closed-end fund discount is from Neal and Wheatley (1998) (for years 1962 through 1993), CDA (1994 through 1998), and The Wall Street Journal end-of-year issues (1999 through 2000). Fama-French factors are SML, HML, and MOM, from Professor French's website. The Heckman correction in model (7) uses the following selection model:

$$
\text { SELECTED }=f(M K T C A P, S E P 500, \text { ASSETS), }
$$

where MKTCAP is market capitalization, SEP500 is whether the firm is ever in the S\&P 500, and ASSETS is total assets. Observations cannot be involved in acquisitions or mergers, the market-to-book and $Q$ must be between 0.1 and 100, sales, assets, capital expenditures, income before earnings and interest, common dividends, common equity must all have non-negative values. Estimations are done with heteroskedastic-robust standard errors (in brackets below) and clustered around firms to minimize serial correlation.

\begin{tabular}{|c|c|c|c|c|c|c|}
\hline \multicolumn{7}{|c|}{ Panel (a) } \\
\hline & $(1)$ & $(2)$ & (3) & $(4)$ & $(5)$ & $(6)$ \\
\hline INVENTORY & $\Delta$ inventory & $\Delta$ inventory & $\Delta$ inventory & $\Delta$ inventory & $\Delta$ inventory & Inventory/PPE \\
\hline \multicolumn{7}{|l|}{ BEHAVIORAL } \\
\hline CAPM alphat-1 & $.002(.000)$ & $.002(.000)$ & $.002(.000)$ & $.002(.000)$ & $.002(.000)$ & \\
\hline Closed-end fund discountt-1 & & & & & & $-.030(.008)$ \\
\hline \multicolumn{7}{|l|}{ FUNDAMENTALS } \\
\hline$\Delta$ Cash flow & $.058(.002)$ & $.058(.002)$ & $.058(.002)$ & $.058(.002)$ & $.057(.002)$ & \\
\hline$\Delta$ Sales & $.500(.010)$ & $.500(.010)$ & $.500(.010)$ & $.495(.010)$ & $.495(.010)$ & \\
\hline$q_{\mathrm{t}-1}$ & & & & & & $.026(.013)$ \\
\hline \multicolumn{7}{|l|}{ INVENTORY-DISCOUNT based on } \\
\hline$t+3$ return differences of by inventory quartiles & $.045(.012)$ & & & & & \\
\hline$t+2$ return differences of by inventory quartiles & & $.072(.013)$ & & & & \\
\hline$t+1$ to $t+3$ return differences of by inventory quartiles & & & $.034(.006)$ & & & $.150(.047)$ \\
\hline $\mathrm{t}+1$ to $\mathrm{t}+3$ return differences of $\Delta$ inventory/PPE quartiles & & & & $.024(.006)$ & & \\
\hline MTB differences of inventory quartiles & & & & & $-.192(.014)$ & \\
\hline Firm fixed effects & & & & & & Yes \\
\hline Adj $R$-squared & .507 & .507 & .507 & .502 & .513 & .837 \\
\hline$N$ & 88,722 & 88,722 & 88,722 & 85,932 & 97,917 & 66,199 \\
\hline
\end{tabular}


Panel (b)

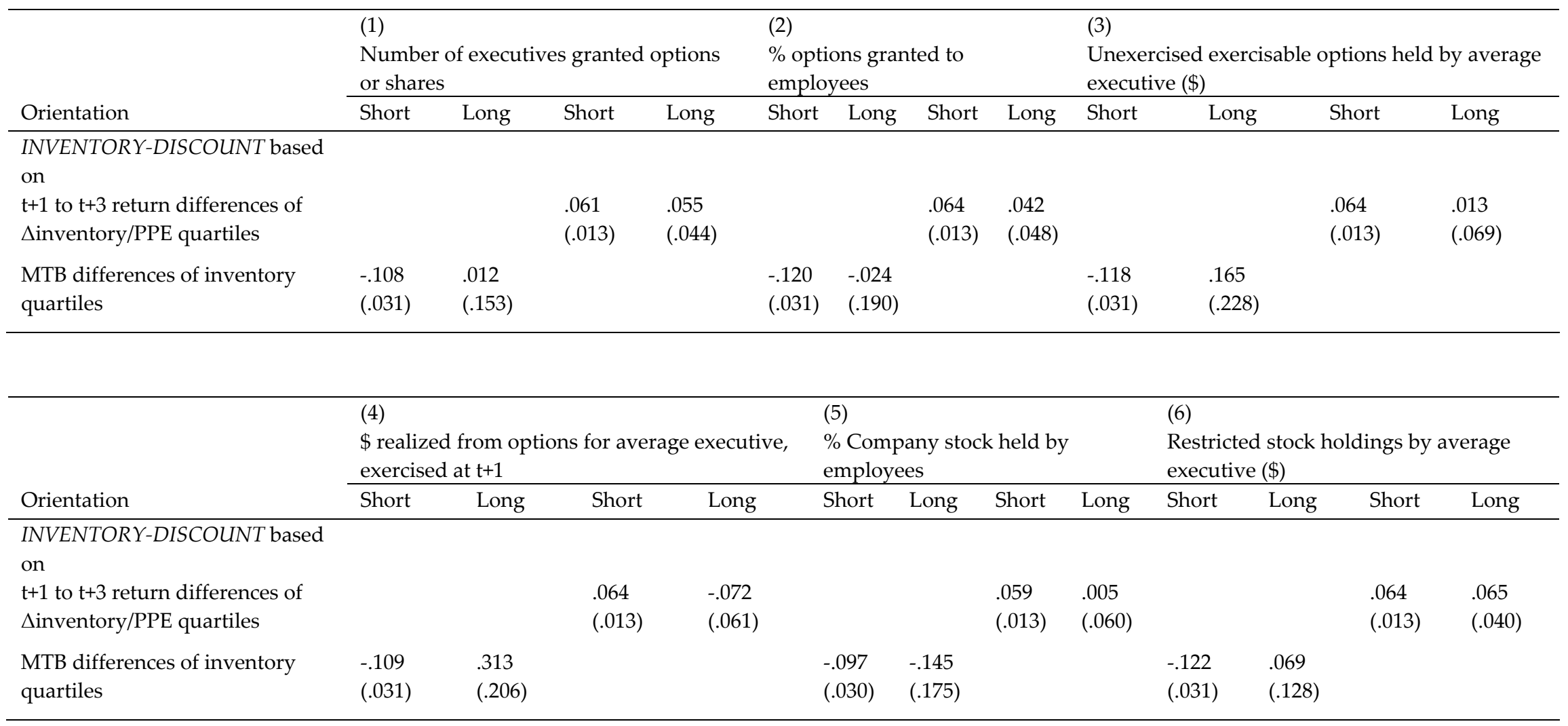

